\title{
ethic@ \\ QUEM TEM MEDO DA LIBERDADE DE EXPRESSÃO? O CIDADÃO DE BEM E O AGITADOR NO TRATADO TEOLÓGICO-POLÍTICO DE ESPINOSA ${ }^{1}$
}

\author{
WHO'S AFRAID OF FREEDOM OF SPEECH? \\ THE GOOD CITIZEN AND THE AGITATOR IN SPINOZA'S \\ THEOLOGICO-POLITICAL TREATISE
}

\author{
ANTÔNIO DAVID 2 \\ (USP/Brasil)
}

\begin{abstract}
RESUMO
O artigo examina o problema da separação entre Estado e religião e o tema da liberdade de expressão no Tratado teológico-político de Espinosa. Tomando como ponto de partida a recepção da obra no contexto de seu aparecimento, e chamando a atenção para as transgressões que ela realiza, procura-se mostrar de que maneira o Tratado teológico-político toma parte no imaginário político holandês, e por que a escolha da fundação e da ruína do imperium hebreu por Espinosa é estratégica. Desmentindo o senso comum de que na República das Sete Províncias Unidas havia total liberdade de pensamento e de expressão, o Tratado teológicopolítico revela um quadro de tensões e impasses no contexto da República, razão pela qual Espinosa realiza nessa obra a defesa da liberdade de opinião. Ao cabo, contrapondo-se às tradicionais imagens do "cidadão de bem" (o que submete sua opinião às autoridades civis) e do "rebelde" ou "agitador" (o que age contra a autoridade civil e instiga outros a fazê-lo), o capítulo final realiza uma crítica imanente ao pensamento vulgar, revelando que, afinal, os "verdadeiros agitadores" são aqueles que almejam cercear a liberdade de expressão.
\end{abstract}

Palavras-chave: Estado; Religião; Liberdade de pensamento; Liberdade de expressão.

\begin{abstract}
The article examines the problem of separation between State and religion and the issue of freedom of speech in Spinoza's Theologico-political treatise. The starting point for the exam is the reception of the work in its advent context, and its transgressions. Based on it, the article aims to show how the Theologico-political treatise takes part in the Dutch political imaginary, and why Spinoza's choice of the hebrew imperium foundation and ruin is strategic. Contradicting the common place that there was full freedom of though and speech in the Republic of the Seven United Netherlands, this book reveals a quite different situation of tensions and deadlocks in the context, which is why in this work Spinoza supports the freedom of opinion. At the end, confronting the traditional images of the "good citizen" (who submits his or her opinion to civil authorities) and the "rebel" or "agitator" (who acts against civil authority and encourages others to do so), the final chapter makes a criticism which is immanent to the vulgar thought, and
\end{abstract}


reveals at the end that the "true agitators" are those who aim to annihilate freedom of speech.

Keywords: State; Religion; Freedom of thought; Freedom of speech.

\section{Introdução}

No dia 15 de agosto de 1672, no contexto das guerras contra os reinos da França e da Inglaterra, o príncipe da Casa de Orange-Nassau, Guilherme III, autorizou a publicação da carta que seu tio, o rei Carlos II da Inglaterra, enviou-lhe em 18 de julho, na qual declarava ter entrado em guerra com a República das Sete Províncias Unidas "para humilhar o orgulho" da facção republicana à frente do poder de Estado desde 1650, ano da morte de Guilherme II. No quadro de polarização crescente entre republicanos e monarquistas ou orangistas, a publicação da carta foi o fator crítico que jogou a "fúria popular" contra os primeiros: no dia 20 de agosto, em Haia, uma multidão ataca o Grande Pensionário da república e efetivo chefe de governo, Johan De Witt, e seu irmão Cornelius De Witt. Eles são assassinados e seus corpos são mutilados e expostos. O príncipe, pela voz de seus auxiliares, logo procurou esquivar-se do acontecido (TROOST, 2016, 74-75, 85-86). No mesmo período, um panfleto anônimo (e contrário a De Witt) denuncia a "ralé", isto é, "todo tipo de vagabundos que, em todos os tempos, querem mudanças e conflitos a fim de poderem pilhar e roubar, assassinar e queimar". Espalhado pouco depois deste episódio, o panfleto contrapõe a ralé ao povo, isto é, aos "cidadãos bons e honestos" (CHAUI, 2003, 270-271).

Publicado dois anos antes, o Tratado teológico-político traz consigo a marca das tensões e dos impasses da conjuntura de sua publicação. Polarizado entre duas tendências igualmente aristocráticas ${ }^{3}$, o imaginário político holandês prescrutado nessa obra, e compartilhado pelas forças em luta, envolve representações de longa sedimentação, filtradas e ressignificadas pela Igreja reformada (CHAUI, 2003, 265-288). ${ }^{4}$ Tome-se o caso limite da tirania. Ao abordá-la, Calvino estabelece a condição sob a qual a revolta contra o tirano deve ser considerada justa:

[...] embora a punição de uma autoridade desordenada seja ato de vingança de Deus, não devemos concluir que ela nos tenha sido confiada e seja lícito exercê-la; cabe-nos apenas obedecer e suportar. Refiro-me sempre a pessoas particulares. Porque, se em nossos dias existem magistrados instituídos para a tutela do povo e para conter a excessiva licença e a cobiça dos soberanos, $[. .$.$] a estas pessoas, que$ estão investidas de autoridade, não posso de modo algum 
proibir, segundo as exigências de seu ofício, que façam oposição e resistam à excessiva licença dos reis, pois, deixando e fazê-lo, trairão ao dever de proteger a liberdade do povo (CALVINO, 2009, 901).

Embora o escopo da passagem seja limitado à questão da tirania, a tese de que devemos "apenas obedecer e suportar" é de abrangente validade e constitui um cânone para orangistas e republicanos. Não surpreende que logo após o mencionado acontecimento, Jean Roth, um opositor do príncipe de Orange-Nassau e próximo do puritanismo escocês, tenha evocado a religião em sua denúncia profética daquele ato: "Um espírito de irreligião, de rebelião e de obstinação reina entre vós. Se continuais a desprezar a voz de Deus, conhecereis ruína e putrefação" (ROTHE apud FRIJHOFF, 1978, 316). Porque o povo permanece obrigado a se submeter em qualquer situação, Calvino rompe apenas parcialmente com a tradição tomista, pela qual "devemos ser reverentemente submissos, tanto aos senhores bons e moderados, como também aos perversos" (TOMÁS DE AQUINO, 1995, 154). Dessa ótica, por baixo das divergências que separam facções políticas e seitas religiosas, acentua-se a longa duração de uma ideia e de práticas que Ihe acompanham.

Mas se, sob a pena de Calvino e de tantos outros antes e depois, a submissão aparece como norma, a pesquisa histórica tem mostrado que os populares atuavam com protagonismo na cena política holandesa da primeira modernidade, de que o episódio de 1672 é emblemático. No centro das relações de poder que atravessam toda a sociedade holandesa, estava a religião.

\section{Estado e religião}

Nesse contexto histórico, entendemos por que o Tratado teológicopolítico (1670) foi recebido com horror e temeridade quando de seu aparecimento (MOREAU, 2002; STEENBAKKERS, 2010; NADLER, 2011, 215-240). São várias as rupturas que Espinosa realiza nessa obra em face das posições tradicionais: em primeiro lugar, Espinosa nega que o contrato seja causa do corpo político, afirmando, bem ao contrário, ser seu efeito, como se observa na narrativa bíblica da instituição do imperium hebreu: o pacto foi ratificado e firmado por Deus "apenas depois de os hebreus terem experimentado sua admirável potência" (TTP, XVII, G. 205-208); ${ }^{5}$ em segundo lugar, ele nega que a preservação do imperium dependa centralmente das virtudes do governante e do temor reverencial dos 
súditos, afirmando depender fundamentalmente da vigência de arranjos institucionais que, de um lado, garantam a igualdade entre todos os seus habitantes, inclusive no que tange às condições materiais de vida (trabalho e propriedade), e, de outro, induzam à moderação do exercício do poder: tais arranjos atestariam a justa proporção [ratio] do imperium hebreu (TTP, XVII， G. 203, 208-217)(CHAUI, 2003, p. 184-93); ${ }^{6}$ em terceiro lugar, Espinosa afirma ser a democracia, e não a monarquia e a aristocracia, o regime mais estável, posto ser o imperium democrático "o mais natural e o que mais se aproxima da liberdade que a natureza reconhece a cada um", isto é, aquele no qual todos permanecem iguais, o que, no caso do imperium hebreu, fora mimetizado na forma de uma teocracia (TTP, XVI, G. 193-195, 239-242; XVII, G. 206; XIX, G. 230). ${ }^{7}$ Em que pese o impacto dessas rupturas, o escândalo provocado por essa obra deveu-se, no entanto, a uma quarta transgressão.

Uma vez tendo localizado o problema fundamental na maneira pela qual se deve instituir um imperium de modo a induzir todos, seja qual for sua maneira de viver, a preferir o direito público às comodidades privadas - questão cuja premência anos mais tarde exigirá de Espinosa, no Tratado político, o oferecimento de complexos arranjos institucionais -, ele nota que "nunca se atingiu um ponto em que o imperium não estivesse mais ameaçado pelos cidadãos do que pelos inimigos e em que os que detêm o imperium não tivessem mais medo daqueles do que destes", para então oferecer o exemplo de Roma, "invencível ante os inimigos e tantas vezes vencida e miseravelmente oprimida pelos seus cidadãos" (TTP, XVII, G. 203-204). Amparando-se na historiografia romana, Espinosa localiza na relação entre Estado e religião a fragilidade do regime romano:

[...] os que tinham anteriormente usurpado o imperium tentaram, para garantir a própria segurança, fazer crer que a sua origem ascendia aos deuses imortais. Isso porque pensavam que, se os súditos e todos os outros os considerassem, não como seus semelhantes, mas sim como deuses, suportariam [paterentur] mais facilmente ser governados por eles e entregar-se-Ihes-iam com facilidade (TTP, XVII, G. 204).

Semelhante "simulação" [simulatio] logrou em muitas ocasiões fazer crer que "a majestade é sagrada, que faz na terra as vezes de Deus, que foi instituída por Deus e não por sufrágio e consentimento dos homens, e que, ademais, conserva-se e defende-se por especial providência e auxílio divino" (TTP, XVII, G. 205). Ao lado de Roma, Espinosa oferece um exemplo contemporâneo, tido por ele como "flagrante" do que dissera: a Revolução 
Inglesa. Segundo nosso autor, depois de ter procurado argumentos para liquidar o monarca "salvando as aparências do direito", o povo inglês nada mais fez que mudar a forma de governo, reconhecendo um novo monarca sob outro nome, "como se toda a questão fosse apenas o nome" (TTP, XVII, G. 227). Em ambos os casos, na gênese dos conflitos intestinos que desembocaram em guerras civis e que deram origem a tiranias, o fator crítico central foi o uso político da religião.

O caso do imperium hebreu não fugiu a essa regra. Instituído por Moisés para garantir a segurança de todos, o efeito foi, também aqui, o oposto do que se pretendeu. A explicação oferecida por Espinosa é particularmente sutil, e para capturá-la é necessário ultrapassar a mera constatação de que o imperium hebreu foi uma "teocracia", dando a devida atenção ao significado dessa palavra à luz das características do imperium. Afora o próprio fato de "teocracia" pressupor uma ficção de Deus da qual a Ética já se ocupara e que, não por acaso, será novamente criticada no Tratado teológico-político, ${ }^{8}$ devemos reter dois argumentos em particular: aquele, veiculado nessa segunda obra, pelo qual, a despeito da fachada teocrática, Moisés foi na prática "rei absoluto" [rex absolute] (TTP, XIX, G. 230), e aquele que figura no Tratado político, segundo o qual um só não é capaz de carregar o peso do imperium, de modo que os regimes ditos monárquicos na prática nunca o são; em verdade, ou são aristocracias tácitas (como é expressamente dito) ou são democracias tácitas (como podemos inferir) (TP, VI).

Assim, se por trás do nome "teocracia" havia uma monarquia, esta, por sua vez, escondia duas tendências antagônicas: de um lado, uma tendência democrática, dada pela presença de instituições marcadamente igualitaristas (DAVID, 2019b); de outro, e em contrapartida, uma tendência aristocrática, a saber, o privilégio conferido aos levitas de interpretar as leis. Se Moisés ancorava seu poder no povo, ao mesmo tempo foi ele quem, valendo-se desse poder, conferiu à sua própria tribo o dito privilégio (TTP, XVII, G. 217-221; XVIII, G. 226; XIX, G. 230). Após a morte de Moisés, o choque entre o povo e os "homens ociosos" desencadeou uma série de acontecimentos que, ao cabo, levaram à ruína do imperium. ${ }^{9}$ Ao lado das imposições materiais que fomentaram a desigualdade em seu interior, Espinosa não deixa de dar ênfase aos "Teologastros" dos levitas (TTP, XVII, G. 218).

Daí entendemos as afirmações de Espinosa de que, "se a república fosse constituída [constituta] de acordo com o projeto, a cada uma das tribos caberia igual direito e dignidade [jus et honor] e tudo se teria mantido em perfeita segurança", mas, em verdade, os hebreus "tiveram contra si a 
ira de Deus, não só, como diz Jeremias, XXXII, 31, desde a conclusão [condita] da cidade, mas logo desde a conclusão [conditis] das leis" (TTP, XVII, G. 217-218), bem como de que a transferência do direito para Deus realizada pelos hebreus "só pôde ser feita muito mais como intenção [mente] do que como realização [opera]" (TTP, XIX, G. 230). A conclusão a que Espinosa chega acaba por relativizar as referências ao imperium hebreu que abrem o capítulo XVII do Tratado teológico-político, e com que abri o presente ponto.

Diante de semelhante ensinamento da experiência, a quarta ruptura realizada por Espinosa no Tratado teológico-político é a contundente defesa da separação entre Estado e religião. Esta acompanha a separação entre razão e fé, ou entre filosofia e teologia, a qual dá título ao capítulo XVI: "nem a teologia está a serviço da razão, nem a razão da teologia" (TTP, XVI, G. 180). Convém aqui notar que Espinosa não se contrapõe apenas à subordinação do poder temporal pelo poder espiritual (posição agostiniana), como se costuma ressaltar entre seus intérpretes; ele se contrapõe igualmente à subordinação inversa, qual seja, do poder espiritual pelo poder temporal (posição eusebiana) - ambas as contraposições são realizadas no capítulo XVIII (TTP, XVIII, G. 222-226). ${ }^{10}$ Todavia, é preciso certo cuidado para a depreensão da posição espinosana: ao lado da total separação, no capítulo XIX Espinosa faz a defesa da limitação da religião pelo imperium.

Ao defender que "o direito em matéria religiosa [jus circa sacra] pertence integralmente [omnino esse] às supremas potestades", ${ }^{11}$ que os detentores do imperium são "intérpretes e defensores [vindices] do direito sagrado [jus sacrum]" e que, enfim, tanto pela experiência como pela razão é óbvio que "o direito divino [jus divinum] depende [pendere] apenas da decisão das supremas potestades", as quais são também suas intérpretes, nosso autor parece à primeira vista sustentar a posição eusebiana (TTP, XIX, G. 228, 232). Não é o caso.

Para dirimir a aparente contradição, deve-se levar em conta que, em Espinosa, todo e qualquer direito que não o direito natural, no que se inclui o direito divino ou religioso, "tem origem num pacto", fora do qual existe apenas e tão somente o direito natural, razão pela qual numa república todo o direito pertence a quem detém o imperium (TTP, XVII, G. 221; XIX, G. 231-233). Isso não implica, porém, que as supremas potestades tenham o direito de definir e estabelecer os fundamentos da Igreja e sua doutrina, de administrá-la, de eleger os ministros, de admitir e excomungar quem quer que seja, em suma, de interferir na religião. Implica, sim, que ninguém tem esse direito "a não ser por autoridade ou concessão destas [nisi ex eorum authoritate vel concessu]", isto é, das autoridades civis (TTP, XIX, G. 2345). A questão então é: como garantir que a dita "concessão" não seja uma 
interferência de fato? Afinal, se o for, então a posição espinosana é uma versão invertida da posição gelasiana, pela qual se reconhece a separação entre os poderes temporal e espiritual e se reclama a interferência da autoridade religiosa na política, pleito e prática marcantes na primeira modernidade. Tampouco é esse o caso.

Para que se enfrente a questão, é necessário observar a sucessão de argumentos entre os capítulos XVI e XIX do Tratado teológico-político. No capítulo XVI, o acento recai sobre a ameaça que determinado uso político da religião representa ao direito civil (tradição eusebiana) (TTP, XVI, G. 199-200). Já no capítulo XVII, Espinosa argumenta não haver contradição entre usufruir do direito de pregar livremente e usufruir desse mesmo direito "por autoridade ou concessão" das autoridades civis, valendo-se, para tanto, do exemplo histórico do imperium hebreu (TTP, XVII, G. 201202). No capítulo XVIII, por seu turno, a fim de provar, pela experiência, a verdade de suas teses, Espinosa retira princípios gerais a partir do exemplo do imperium hebreu: notando ser pernicioso, tanto para a religião como para o imperium, a concessão aos sacerdotes de se intrometerem em assuntos públicos, Espinosa argumenta: "haverá muito mais estabilidade [constantius] se eles estiverem sujeitos a dar a sua opinião só quando forem solicitados e que, quando não for o caso, sejam limitados [contineantur] a ensinar e a praticar só o que for maximamente usual e costumeiro" (TTP, XVIII, G. 225).

Mirando na dependência do direito divino em relação à autoridade religiosa, Espinosa não propõe uma inversão de papéis, o que significa dizer que a posição espinosana não é um espelhamento da posição eusebiana. Com vistas a garantir a segurança, a liberdade e a paz, a consideração atenta dessas passagens deixa ver que Espinosa defende não uma submissão positiva - uma interferência da autoridade civil sobre a religião -, mas uma submissão negativa - uma imposição de limites, suficiente para impedir que autoridades eclesiásticas e seitas religiosas interfiram no poder de Estado. ${ }^{12}$

É certo que Espinosa considera que a limitação do exercício religioso pela autoridade civil favorece a "verdadeira religião", a saber, a prática da justiça e da caridade: ao inibir as incursões de religiosos sobre o Estado e as desavenças que daí nascem, tem-se o caminho livre para transformar a dita prática em força de lei - argumento que figura repetidamente no capítulo XIX, e com o qual Espinosa fechará o tratado (TTP, XX, G. 247, p. 310). Mas entre tornar real o mencionado efeito favorável e evitar os efeitos nocivos da causa que se quer inibir, o acento recai sobre esta, não sobre aquela - o que é compreensível quando se tem em conta a força do 
eusebianismo nos seiscentos. Espinosa não é indiferente a esse contexto. $\mathrm{Na}$ base dessa preocupação encontramos uma constatação histórica de caráter, diríamos hoje, etnográfico:

Todos sabemos, efetivamente, quanta importância o povo atribui ao direito e à autoridade em matérias sagradas e o quanto depende da palavra de quem a possui. Pode mesmo dizer-se que quem tem essa autoridade é quem melhor reina sobre os ânimos [animos regnare] (TTP, XIX, G. 235).

Na sequência, Espinosa adverte que se alguém pretende subtrair esse direito às supremas potestades, é porque está tentando dividir o imperium, "o que, necessariamente, há de originar, tal como outrora entre os reis e os pontífices dos hebreus, revoltas e discórdias impossíveis de sanar", ao que conclui: "quem tenta retirar essa autoridade às supremas potestades prepara-se, como dissemos, para se apoderar [affectat] do imperium". Algumas linhas antes, Espinosa já alertava, em relação aos "muitos [plurimi]" que negam reconhecer às potestades supremas o direito de decidir sobre as questões sagradas e que dão para si mesmos licença para as acusar, as injuriar e até para as excomungar da Igreja, que estes "dividem o imperium e, mais ainda, encaminham-se para dele se apoderar [affectare]" (TTP, XIX, G. 228). Vemos então que o exemplo dos ingleses não figura no texto como uma mera ilustração. No contexto histórico no qual o Tratado teológico-político apareceu, o avanço de seitas religiosas sobre o poder político é uma tendência histórica na Europa e em seus domínios, de que a Revolução Inglesa é expressão particular, o que eleva o patamar da questão a um verdadeiro estado de emergência.

É dessa história que Espinosa fala quando escreve sobre o imperium hebreu. As razões de Espinosa ter escolhido esse caso em particular devemse menos a este ser um caso conhecido no repertório comum nos seiscentos e ao fato de Espinosa conhecê-lo muito bem (inclusive por dominar o hebraico bíblico) e mais ao contexto político específico da República das Sete Províncias Unidas pós-Paz de Münster.

Desde a guerra de independência contra a Espanha, em todas as camadas sociais na República buscou-se enquadrar a história recente na cultura bíblica do Antigo Testamento (designação da Bíblia hebraica no mundo cristão). Tendo-se debruçado sobre fontes do período, Theodor Dunkelgrün mostra que o mito batavo, mobilizado por Erasmo, Grotius e outros, já não era suficiente para explicar o que muitos consideravam ser "uma vitória miraculosa da Holanda sobre o poderoso império espanhol", e que, para tanto, forjou-se a imagem da Neerlands Israel, ou "Israel Holandesa", a qual cumpria a função de articular analogias: se o Império 
Espanhol era o Egito e seu monarca, o faraó, o povo holandês emergia como o povo escolhido, sob a liderança do novo Moisés, o Príncipe de Nassau como tal retratado por Hendrik Goltzius. Nesse contexto, sem deixar de ser fonte de disputas e controvérsias, a "aura hebraica" deitou raízes na cultura popular, tornando-se "um lugar comum" na República (DUNKELGRÜN, 2009, 205).

À luz do enraizamento dessa ideologia no contexto histórico, vemos que a escolha do imperium hebreu por Espinosa é estratégica, assim como são estratégicas a desmistificação da teocracia e da noção tradicional de povo escolhido. Em seu lugar, Espinosa oferece, de um lado, a determinação da verdadeira força do imperium hebreu em seus primeiros anos, enquanto este teve força, a saber, o consentimento de todos na gênese do imperium e a plena igualdade usufruída pelos cidadãos, e, de outro, a determinação das causas da ruína do imperium, a saber, as discórdias nascidas da desigualdade e dos usos políticos da religião. Contra um uso político do passado que reduz a história a metáfora, Espinosa lança mão desse mesmo passado para dele realizar uma "história autêntica" [historia sincera] (TTP, VII, G. 98), isto é, uma história que, amparada em um método crítico, busca descrever e concluir com base em dados certos, ou, como diríamos hoje, evidências. ${ }^{13}$

\section{Liberdade de expressão}

Se todo o problema só tem lugar pela "importância o povo atribui ao direito e à autoridade em matérias sagradas" e por "quanto depende da palavra de quem a possui", Espinosa não acaba por corroborar a tradicional imagem da má índole do popular? Não estará aí a explicação para a tentativa fracassada de acomodação da religião ao interesse comum envolvida na história do imperium hebreu? Se, também nesse ponto, pretende-se que a canônica imagem da insubmissão e rebeldia do povo hebreu prefigura a imagem dos holandeses como "facciosos por natureza" - e que, como outrora Moisés, "apenas o Príncipe de Orange poderia manter a harmonia interna em uma federação de províncias dividida em facções" (STERN, 2009, 33-7), não teria Espinosa, ao fim e ao cabo, reforçado e sancionado essa imagem? Em uma palavra, qual é o lugar dos subalternos na filosofia política de Espinosa?

O capítulo XX do Tratado teológico-político oferece a chave para que se enfrente a questão. Para tanto, deve-se examinar a posição do agente na construção conceitual e argumentativa do capítulo, bem como atentar para dois deslocamentos conceituais que nele têm lugar, e que permitem a 
Espinosa a um só tempo afastar a imagem atribuída aos subalternos pela tradição e, no mesmo movimento, realizar a defesa da liberdade de expressão. ${ }^{14}$

Tendo asseverado ser impossível mandar nos ânimos [animis] como o é mandar nas línguas, que as opiniões pertencem ao direito individual [uniuscuejusque jus], que "ninguém [nemo], mesmo que quisesse, poderia renunciar-lhe"15 e que, portanto, um poder que se exerce sobre o foro íntimo "se tem por violento", ${ }^{16}$ e tendo reconhecido que, apesar disso, a liberdade de expressão não pode ser totalmente [ominino] concedida, e perguntando-se "até que ponto [quousque]" ela pode e deve ser concedida sem prejuízo à paz social e ao direito das autoridade civis, Espinosa responde, à luz do que anteriormente fora exposto sobre a finalidade do imperium - não dominar, subjugar, submeter ou "transformar os homens em bestas ou autômatos", mas promover a liberdade, ou seja, garantir a todos, da melhor maneira, e sem prejuízo a si mesmo e a outros, "o direito natural a existir e agir [jus naturale ad existendum et operandum]" -, que tal limite é dado especificamente pela ação, ou seja, que o direito das potestades supremas e a paz dependem de os súditos renunciarem ao direito de agir segundo o próprio parecer [ex próprio decreto], ao que conclui: deve-se garantir a cada um o direito de pensar, julgar e dizer o que quiser, "desde que se limite apenas e tão somente a [modo simpliciter tantum] dizer ou ensinar, e a sustentar unicamente pela razão, sem fraude, cólera, ódio, o que quer que seja do que deve ser introduzido na república, e não com a intenção [animo] de fazê-lo pela autoridade de seu parecer [ex authoritate sui decreti]" (TTP, XX, G. 239-41). Para exemplificá-lo, Espinosa argumenta:

"Suponhamos, por exemplo, se alguém mostra por quaisquer meios que uma lei é contrária à sã razão e, em consequência, pronuncia-se por sua revogação, e se, ao mesmo tempo, submete sua opinião [suam sententiam... submititt] ao juízo das potestades supremas (a quem cabe exclusivamente promulgar e revogar as leis) e nesse meio tempo nada faz [agit] contrariamente ao que está prescrito na mesma lei, nesse caso, ele é, sem dúvida alguma, tão merecedor da republica como qualquer cidadão de bem [optimus civis]; mas, se, pelo contrário, o fizer para acusar [id faciat ad accusandum] de iniquidade o magistrado e o tornar odioso aos olhos do vulgo, ou se de maneira sediciosa tenta revogar [studeat aborogare] essa lei contra a vontade [invito] do magistrado, então, trata-se de um agitador [perturbator], um rebelde [rebellis]" (TTP, XX, G. 241). 
Tal é a medida ou proporção [ratio] pela qual um indivíduo pode se expressar livremente, sem perigo para o direito das supremas potestades e para a paz do imperium (TTP, XX. G. 241, 242, p. 303-4). Até aqui, ao localizar os agentes em contraste, Espinosa parece à primeira vista convergir com a tradição: de um lado, o "cidadão de bem" e sua submissão reverencial às leis, inclusive àquelas das quais discorda - nesse caso, sem deixar de pronunciar-se contra as leis a que se opõe, o "cidadão de bem" as submete ao magistrado, abstendo-se de agir contra elas e de instigar outros a fazê-lo em qualquer situação; de outro, o "agitador" ou o "rebelde", que pensa e se expressa com má intenção - atente-se que, nessa situação, sequer é necessária a tentativa de tomada do poder, sendo sediciosa qualquer tentativa de mudar a lei que não a submissão da opinião às autoridades ("tenta revogar essa lei contra a vontade do magistrado") ou mesmo o simples ato de expressar-se ("para acusar de iniquidade o magistrado e o tornar odioso aos olhos do vulgo"). Dessa ótica, parecendo chancelar a criminalização de certas opiniões, Espinosa não teria se afastado tanto do imaginário político tradicional. ${ }^{17}$

Contudo, o que aqui se coloca é apenas um ponto de partida, no qual figura não a posição de Espinosa, mas o ponto de vista vulgar, um senso comum entre teóricos e políticos no contexto. Da perspectiva do vulgar, pouco importa o que leva os indivíduos a agir dessa ou daquela maneira; o que conta é a ação em si mesma e a suposta índole dos indivíduos que agem (as designações "cidadão de bem", de um lado, "rebelde" ou "agitador", de outro, são marcadores sociais através dos quais se pretende fixar um caráter), em um raciocínio circular: a ação é tida como suficiente como índice da índole, e a índole é tida como suficiente para explicar a ação. O que ampara um tal raciocínio é, de um lado, a crença no livre-arbítrio, e, de outro, a submissão como um dever incondicional. ${ }^{18}$ Disso é sintomática a incongruência entre a abertura e a conclusão do parágrafo: se é impossível mandar nos ânimos, como justificar que o limite do direito de expressão se dê justamente pela intenção? Tal é o ponto de partida do argumento, sobre o qual Espinosa realizará uma crítica imanente, e que consistirá em, operando sobre essa mesma lógica fixadora, evidenciar a incoerência do pensamento vulgar. ${ }^{19}$

Na sequência, após reafirmar a posição vulgar, há uma primeira mudança de registro, pela qual a ênfase desloca-se de quem opina para quem almeja enquadrar ou controlar a opinião de outros. Uma vez reconhecendo que inconvenientes [incommodi] ocorrem e até são inevitáveis onde a liberdade de opinião é assegurada, mas asseverando que estes podem ser contornados [vitari] pelas autoridades civis, Espinosa é 
taxativo: "Quem tudo quer fixar na lei acaba por assanhar [irritabit] os vícios em vez de os corrigir. Aquilo que não se pode proibir tem necessariamente que se permitir, não obstante os danos [damnum] que muitas vezes daí advêm" (TTP, XX, G. 243). É nítida a contrariedade entre essa posição e a que fora veiculada poucas linhas antes. Agora, ao contrário de subscrever o cerceamento de certas opiniões - aquelas que implicam em determinada ação -, Espinosa indica que nenhuma opinião deve ser criminalizada. Tal é a posição espinosana, como veremos no final.

Como um primeiro passo da qualificação de sua posição, Espinosa precisará lidar com o complicado problema da resistência. Para tanto, há uma nova mudança de registro no texto, e o acento desloca-se agora para quem sofre a censura. Espinosa traça dois cenários base para a situação em que a censura é imposta: enquanto alguns dissimularão, isto é, pensarão uma coisa e dirão outra, o que favorecerá a (não necessariamente levará à) adulação, a perfídia e a corrupção dos costumes, ${ }^{20}$ já outros mais obstinadamente resistirão quanto mais se procurar retirar deles a liberdade de expressão. Estes, segundo Espinosa, não são "os avaros, os bajuladores e outros de ânimo impotente", mas "aqueles a quem uma boa educação, a integridade de costumes e a virtude tornaram ainda mais livres [quos bona educatio, morum integritas et virtus liberiores fecit]" (TTP, XX, G. 243-4). Na sequência, Espinosa argumenta:

Os homens, na sua maior parte [plerumque], são constituídos de tal maneira [ita constituti sunt] que não há nada que eles suportem com mais impaciência [impatienter ferant] do que ver as opiniões que julgam verdadeiras tidas como crime [pro crimine habeantur] e o que os estimula à piedade para com Deus e para com os homens considerado como delito [sceleri reputetur], do que resulta detestarem [detestari] as leis, atreverem-se a recorrer à força contra os magistrados e julgar que é a coisa mais honesta e não uma vergonha fomentar com tal pretexto sedições e cometer toda a espécie de crimes. Sendo, portanto, que a natureza humana é assim disposta [comparata], segue-se de as leis em matéria de opinião levam em consideração [respicere] não os vilões [scelestos], mas os francos [ingenuos], e levarem [condi] não à contenção [coercendeum] dos maus [malignos], mas, ao contrário, à irritação [irritandum] dos honestos [honestos], além do que não poderem manter-se sem grave risco para o imperium (TTP, XX, G. 244).

Para a interpretação dessa passagem e do trecho imediatamente anterior, é crucial levar em conta dois dados: primeiro, que aqui Espinosa 
faz menção não a todos os homens, mas aos homens "na sua maior parte [plerumque]" - o que remete aos costumes (no que se incluem as leis e a religião) e, portanto, ao contexto histórico -, e como logo a seguir ele faz menção à disposição da natureza humana, devemos reter o seguinte da passagem: dada a natureza humana, os indivíduos tendem a se comportar de uma determinada maneira e não de outra por força dos costumes; ${ }^{21}$ segundo, e por conseguinte, que o que resulta desse não suportar (detestar as leis, atrever-se a recorrer à força contra os magistrados e julgar que é a coisa mais honesta e não uma vergonha fomentar com tal pretexto sedições e cometer toda a espécie de crimes) é apenas uma maneira de resistir. Outra maneira é a dos que agem com franqueza e honestidade, e consiste em "pensar livremente" e usufruir livremente do direito de opinar - é o que Espinosa indicará a seguir. ${ }^{22}$ Quanto à designação "aqueles a quem uma boa educação, a integridade de costumes e a virtude tornaram ainda mais livres", ela não diz respeito à virtude como uso da razão, mas à virtude como força de ânimo, em um sentido próximo da virtù maquiaveliana. ${ }^{23}$ Nela cabem todos, os "maus" e os "honestos".

Feitas as ressalvas, o mais importante é que aqui Espinosa desloca o foco da questão. Nesse momento, joga-se luz não mais para a ação em si, mas para o que move os indivíduos a agir. Com isso, os marcadores (os pares "vilões" e "francos", "maus" e "honestos") não têm a mesma função que o par "cidadão de bem" e "agitador", pois não são explicativos da ação; sua função é meramente descritiva. Do ponto de vista explicativo, o agente da ação, por excelência, são "os homens", tal como são estes constituídos (possuidores de uma natureza e atravessados por costumes). É sob esse pano de fundo que Espinosa situa ética e historicamente a ação, ao contrário do vulgar, que encara determinada maneira de agir em si mesma, o que acaba por essencializar as condutas. Em outras palavras, para Espinosa os homens não são "maus" ou "honestos", mas agem de acordo com o significado que se atribui a tais denominações, mesmo quando a ação é habitual. ${ }^{24}$ Trata-se não de um ser, mas de um tornar-se que nunca é fixo, mas contínuo e fluido, porque depende da maneira como vivemos e experimentamos as determinações que nos atravessam, o que, por seu turno, depende de nossa história de vida, bem como do contexto e das circunstâncias (David, 2019a). Tal é o primeiro deslocamento, pelo qual a ênfase passa do caráter do agente, tomado pelo vulgar de maneira abstrata, às causas da ação.

O índice de que Espinosa realiza uma crítica interna ao pensamento vulgar está na curiosa duplicação ao final da passagem: do par "vilões" e "francos" ao par "maus" e "honestos". O que justifica que um autor tão 
cuidadoso com as palavras tenha cometido o que parece ser uma redundância? Na verdade, entre os dois enunciados há uma sutil diferença: o primeiro par faz alusão a ações passadas; o segundo, a ações futuras - o índice dessa diferença é dado pelo verbo: "levar em consideração" [respicio], "levar a" [condo]. ${ }^{25}$ Ocorre que entre uma ação passada e uma ação futura há uma diferença ontológica nada desprezível: a ação passada teve existência e, como tal, foi determinada - pode-se afirmá-lo, ainda que a íntegra de sua determinação seja sempre inalcançável; a ação futura não existe - logo, a ela não se aplica o conceito de determinação. A construção argumentativa do parágrafo trabalha criticamente sobre a ilusão vulgar de que os indivíduos são isso ou aquilo, e de que, sendo o que são, agirão sempre da mesma maneira, o que implica em uma determinação do futuro - tal é a pretensão vulgar, posta no primeiro enunciado, como se as designações "vilões" e "francos" participassem da natureza ou da essência dos indivíduos. O que se perde com uma tal visão das coisas é justamente a noção de que a maneira como os indivíduos agirão no futuro não é previamente determinada, mas dependerá de uma série de fatores contextuais e circunstanciais que não podem ser todos conhecidos de antemão. As leis e seu peso sobre os indivíduos são um desses fatores, e é exatamente isso que o segundo enunciado acentua: à luz da natureza humana e dos costumes, as leis em matéria de opinião incitam a irritação em alguns - o que Espinosa afirma explicitamente - , e incitam, por ausência de contenção, a maldade em outros - o que está nela implícito. Este enunciado, não o primeiro, oferece, a um só tempo, a gênese da conduta (a rigor, de parte dela), e o erro do primeiro enunciado. Tal é, a meu ver, a razão da duplicação no argumento, a qual, realizando-se no interior do pensamento vulgar e subvertendo-o, marca a passagem da posição vulgar à posição propriamente espinosana.

Se as opiniões e os estímulos podem ser diversos, em qualquer caso - dirá Espinosa - as leis em matéria de opinião são de todo inúteis: por um lado, aqueles que acreditam que são corretas as opiniões que as leis condenam não podem obedecer a essas mesmas leis; de outro, quem as rejeita como falsas "considera um privilégio as leis que as condenam e sentir-se-á por isso de tal maneira triunfante que o magistrado, mesmo que queira, já não consegue depois revogá-las", o que é confirmado pela história dos hebreus (TTP, XX, G. 244). Todos resistirão, ainda que, como vimos, não de uma só maneira. Mas a inutilidade é apenas um lado da moeda; o outro lado, o que merece atenção e preocupação, é o de sua perniciosidade. Para dar conta deste aspecto, nosso autor realizará um segundo e decisivo deslocamento conceitual. 
Espinosa inicia esse percurso com a experiência: semelhantes leis "foram frequentemente instituídas", tal é a constatação que ele faz, e o que se tira como lição desses episódios, com inúmeros exemplos, é o fato de tais leis poderem "facilmente transformar em raiva a devoção [devotionem] da plebe sediciosa [seditiosae plebis] e instigá-la [instigare]" contra quem se quer, mas é também o fato de os honestos - isto é, os que agiram ou costumam agir de maneira honesta -, quando perseguidos, tornarem-se exemplos para outros, objeto de imitação e admiração ${ }^{26}$ - portanto, exemplos no sentido inverso daquele pretendido por quem os persegue. É a experiência que agora corrobora a tese de que "quanto menos liberdade de opinião se concede aos homens, mais nos afastamos do imperium mais parecido com o de natureza e, por conseguinte, mais violento é o poder". $E$ é com base na experiência que virá o argumento decisivo (TTP, XX, G. 245).

Com vistas a justificar a tese de que os homens, mesmo professando opiniões contrárias, são "facilmente impedidos de se lesarem uns aos outros" pelas potestades supremas, Espinosa lança mão da República das Sete Províncias Unidas: Amsterdam como exemplo, a República como contraexemplo. Sendo Amsterdam vigorosa pela liberdade de opinião, a República foi ameaçada, conta Espinosa, "quando outrora os políticos e Senadores das Províncias começaram a se envolver na controvérsia dos remonstrantes e contra-remonstrantes sobre religião": esta "degenerou logo num cisma", dando "inúmeros exemplos" de que as leis sobre matéria de religião, supostamente destinadas a dirimir as controvérsias, "servem mais para exasperar os homens do que para os corrigir [homines magis irritare quam corrigere]"; que "há quem retire dessas leis pretexto para toda a espécie de abusos"; e que os cismas nascem "do grande desejo de mandar [libidine regnem]" (TTP, XX, G. 245-6). Reportando-se às guerras de religião que se deram em solo holandês e seus desdobramentos no presente, às graves tensões originadas do uso político da religião e às perseguições que daí foram desencadeadas - e que ele próprio sofria na pele (DAVID, 2021, 439) -, Espinosa conclui:

Donde resulta meridianamente claro, primeiro, que os verdadeiros cismáticos [schismaticos] são aqueles que condenam os escritos dos outros e instigam contra os seus autores a insolência do vulgo, autores estes que, na maior parte dos casos, escrevem apenas para os doutos e se socorrem unicamente da razão; segundo, que os verdadeiros agitadores [revera perturbatores] são aqueles que, num imperium livre, querem abolir a liberdade de pensamento, não obstante ela ser impossível de reprimir (TTP, XX, G. 246). 
Eis o segundo deslocamento: com ele, a imagem do "agitador" (ou "rebelde") com a qual Espinosa abre o capítulo, e que já fora diluída no primeiro deslocamento, é agora inteiramente desconstruída, dando lugar ao "verdadeiro agitador", ao lado do qual figura o "verdadeiro cismático": àqueles que, num imperium livre, querem abolir não só a liberdade de expressão, mas até mesmo a liberdade de pensamento, uma liberdade "absolutamente necessária para o avanço das ciências e das artes", que só podem frutificar sob um "pensamento livre $e$ inteiramente descomprometido" (TTP, G. 243). Por analogia, podemos dizer que o "cidadão de bem", como imagem de uma índole fixa, igualmente sucumbe, dando lugar ao "honesto" - ou, em termos mais rigorosos, ao que, em dada situação, age de maneira honesta -, aquele cuja causa "os inertes e de ânimo impotente ignoram, os sediciosos odeiam e os honestos amam" (TTP, $X X, G .245)$. Ao cabo, pelo movimento interno ao texto, a fonte do perigo à segurança e à liberdade comuns desloca-se de um sujeito essencializado, e que no contexto é vulgarmente associado à plebe, ${ }^{27}$ a um sujeito cuja inteligibilidade é dada pelo desejo que move a ação - desejo de dominar ("verdadeiro agitador"), desejo de submeter-se à dominação ("cidadão de bem") - com La Boétie, podemos indagar: submeter-se para melhor submeter? (CHAUI, 2013, 27) -, desejo de não submeter-se à dominação ("agitador", "rebelde", "honesto"). É certo que tampouco os que desejam dominar e submeter-se à dominação devem ser encarados numa chave essencializadora, pois também estes são incitados a tanto: como Espinosa mostrará no Tratado teológico-político, é sobretudo na vida que levam, favorecida pelo caráter estamental da sociedade, que mora a incitação (DAVID, 2021). Na base de uma gramática social e política que incita tantos indivíduos a agir mal, está a desigualdade. ${ }^{28}$

Donde, em quinto lugar, Espinosa negue que a causa de tumultos e sedições seja a índole sediciosa da plebe: é na ação das autoridades, sob o pano de fundo dos costumes e das leis, que se deve buscar a raiz das revoltas e da insubmissão, como crime ou, como Espinosa dirá no final, como vingança (TTP, G. 247). ${ }^{29}$ Ao olhar para a história, inclusive para seu contexto histórico, Espinosa reconhece na interferência da religião sobre a política a principal fonte de ameaça à paz, à segurança e à liberdade, tanto pública como individual. No núcleo dessa disputa, vemos a liberdade de expressão. 


\section{Conclusão}

A síntese ao final do capítulo XX não deixa dúvida: é impossível tirar aos homens a liberdade de dizer o que pensam; essa liberdade não acarreta em inconvenientes que não possam ser contornados, seja à paz, seja à piedade, seja à autoridade civil; ela não só pode como deve ser concedida, para que se preserve tudo isso; cada um poderá usufruir desse direito, "desde que daí não retire nenhuma liberdade para que seja introduzido o que quer que seja no direito da república [rempublicam jus], ou para agir contra as leis estabelecidas" (TTP, XX, G. 246-247). Na formulação que se oferece ao final, o mando sobre o ânimo despareceu. É apenas e tão somente a ação que conta. Daí que em relação ao argumento que vem logo a seguir, segundo o qual os ânimos [animi] daqueles que professam "opiniões discrepantes" [discrepantium opiniones] podem ir a julgamento [in judicium vocantur], mas não as opiniões (TTP, XX, G. 247), cabe a ressalva: as intenções só podem ser julgadas a posteriori, nunca a priori, o que significa dizer que são os atos que podem ser julgados - e apenas e tão somente através dos atos, julgam-se as intenções.

A posição defendida por Espinosa no capítulo final do Tratado teológico-político coloca uma questão sensível para nós na atualidade. Toda e qualquer opinião deve ser permitida, a salvo de ser criminalizada? Essa é uma ótica privilegiada para compreendermos Espinosa. Para tanto, devemos reter sobretudo a ideia, anteriormente veiculada, de que "aquilo que não se pode proibir tem necessariamente que se permitir, não obstante os danos que muitas vezes daí advêm". Na sequência, Espinosa exemplificará: "Quantos males não derivam da luxúria, da inveja, da avidez, do alcoolismo e de outras coisas parecidas? $E$, no entanto, elas são toleradas porque não está no poder das leis evitá-las, apesar de realmente se tratar de vícios" (TTP, XX, G. 243). Está fora de questão que determinadas opiniões possam ser encaradas como "males" e suscetíveis de provocar "danos". O que Espinosa coloca para nós é a ineficácia de uma postura que hoje chamaríamos de proibicionista e punitivista; em seu lugar, ele defende uma postura que se aproxima do que hoje entendemos como redução de danos. Se, para Espinosa, a proibição e a punição são ineficazes em qualquer contexto, tanto mais o é em contextos nos quais muitos agem mal. Sua posição parte de dois pressupostos fundamentais: primeiro, diante de opiniões, intenções e práticas odiosas e/ou antidemocráticas, a única medida realmente eficaz é defender e fomentar a democracia, isto é, a igualdade, no sentido mais pleno e abrangente da palavra; segundo, dadas as paixões humanas e dado que "a maior parte das nossas ações [são] 
extremamente incertas e cheias de risco [incertae et alea plenae]" (TTP, G. 187), nem mesmo em imperia democráticos haverá a garantia, no sentido forte do termo, de segurança e liberdade, sendo necessária uma permanente vigilância - talvez daí o emblema de Espinosa, Caute (Precaveivos). ${ }^{30}$ 


\section{Notas}

${ }^{1}$ Pela impossibilidade de encontrar, em português, termos que não acarretassem em confusão, optei por manter em latim as palavras imperium, multitudo e civitas. As citações de Espinosa seguem a tradução para o português indicada na bibliografia, bem como a indicação de página; todavia, advirto que fiz alterações de tradução sempre que julguei necessário. Nas citações, optei por manter declinados os vocábulos em latim, tal como se encontram no original.

2 Professor contratado III da Escola de Comunicação e Artes da Universidade de São Paulo (USP). Doutor em Filosofia pela Universidade de São Paulo (USP).

3 Segundo Rowen, a expressão "governo popular", na linguagem da época, significa "uma ampla aristocracia, não uma universal democracia", com seu poder "bem distribuído entre muitas assembleias" (ROWEN, 1986, 31).

${ }^{4} \mathrm{O}$ imaginário político holandês no período.

5 Sobre emprego, em Espinosa, da noção de "pacto", em contraste com seu emprego por Hobbes, ver Balibar (1985); Lazzeri (1987); Lazzeri (1998, 155-240).

${ }^{6}$ Sobre a igualdade no que tange ao trabalho e à propriedade, ver David (2019b).

7 Sobre a democracia como o mais natural dos regimes, ver Aurélio (2000, 277 288); Chaui $(2003,236)$. Sobre a teocracia hebraica, ver James (2010, 269-274). Criticando Espinosa por este supostamente conceber a teocracia como "tão natural quanto a democracia", Leo Strauss vê uma contradição em Espinosa: pois a teocracia, para Strauss expressão política da superstição, pressupõe uma "alienação da natureza" ou do direito natural. Considero a leitura de Strauss equivocada por ignorar que, ao discorrer sobre a teocracia no Tratado teológicopolítico, Espinosa fala de uma teocracia histórica e singular, a teocracia hebraica, e não da teocracia em abstrato, e que esta, embora contivesse elementos democráticos, não equivalia à democracia, como argumentarei a seguir (STRAUSS, $1965,239 s)$.

${ }^{8}$ Em sintonia com o que já fora explicado no Apêndice do Livro I da Ética, lemos no Tratado teológico-político: "não se pode conceber Deus como um príncipe ou um legislador" (TTP, XIX, G. 231; G. 65, 76), não sendo esse o caso sequer no imperium hebreu, cuja história revela que "Deus não exerce nenhum reinado sobre os homens a não ser através daqueles que detêm o imperium" (TTP, XIX, G. 228). Veja-se ainda a conceituação realizada por Espinosa sobre "vontade" e o "entendimento" de Deus (TTP, G. 62-63).

9 Nesse momento, Espinosa faz menção aos "constantes boatos" [continuo rumores] entre o povo, uma indicação da agência subalterna, como a pesquisa histórica tem mostrado. (DAVID, 2019b) 
10 Sobre as posições agostiniana, eusebiana e gelasiana - a esta, farei menção adiante (SCATTOLA, 2009 87-126).

11 Sobre a tradução de summae potestates por "potestades supremas", sigo a opção e a justificativa de Fernando Dias Andrade (ANDRADE, 2015).

12 Não é sem propósito que Espinosa tenha optado pelo verbo accomodo, e não subjicio ("subordinar", "sujeitar"). Presente já no título do capítulo XIX - "o culto externo deve acomodar-se [accommodari] à paz do imperium" (TTP, XIX, G. 228, p. 287) - o termo figurará repetidamente ao longo do capítulo. Sobre a "acomodação" em Espinosa, ver David (2019b, 193s).

13 "A conclusão a extrair de tudo isso é, evidentemente, que a religião adquiriu entre os hebreus força de direito graças unicamente ao direito do imperium e que, destruído este, ela nunca mais pôde ser considerada como direito de um imperium singular, mas sim como ensinamento universal da razão" (TTP, XIX, G. 231).

14 Por ver um paralelo entre os deslocamentos aqui realizados e aqueles que se verificam no parágrafo VII, 27 do Tratado político, os quais foram examinados por Chaui (2003), realizo paralelos na estrutura e no título deste artigo em relação ao artigo de Chaui.

15 Espinosa escreverá no Tratado Político: "ninguém pode ceder a faculdade de julgar" (TP, III, 8); esta pode ser no máximo "enganada [decipi]" (TP, II, 11).

${ }^{16}$ Nesse momento, Espinosa volta a enfatizar o papel dos boatos no seio do povo: "O próprio Moisés, que tinha conquistado por completo a opinião do seu povo [...] não pôde, mesmo assim, escapar aos boatos [rumores] nem às mais sinistras interpretações. Como é que haveriam, então, de escapar os outros monarcas?" (TTP, G. 239).

17 Sobre a censura na República das Sete Províncias Unidas, ver notas da "Carta $44^{\prime \prime}$.

${ }^{18}$ Foge ao escopo deste trabalho o tema do livre-arbítrio em Espinosa. Quero apenas lembrar que, em Espinosa, a recusa do livre-arbítrio não se confunde com a recusa do arbítrio, mas com a recusa da ideia, amplamente compartilhada no pensamento de matriz judaico-cristã, de que o arbítrio é livre de toda e qualquer determinação ou limitação; disso não se segue, como alguns consideram, que em Espinosa o arbítrio se reduza às determinações ou limitações que enformam a ação (o que se convencionou chamar de "necessitarismo"). Tome-se essa passagem do Tratado teológico-político: "O agir de acordo com uma ordem, quer dizer, a obediência, retira, é um fato, até certo ponto a liberdade; não torna, porém, automaticamente um homem escravo, já que só a regra da ação [actionis ratio] pode levar a tanto" (TTP, XVI, G. 195). E, algumas linhas adiante: "seja qual for o motivo [ratione] pelo qual um homem decide executar as ordens das potestades supremas - o medo do castigo, a esperança de obter alguma coisa, o amor da pátria ou qualquer outro sentimento -, ele delibera por sua própria resolução [ex próprio suo concilio deliberat] e não é por isso que ele deixa de agir segundo [ex... 
agit] as ordens das potestades supremas" (TTP, G. 202). Sobre esse ponto, ver David (2019a).

19 O movimento interno ao texto pelo qual o próprio discurso vulgar ou o "senso comum imaginário" produz seu avesso é nomeado por Chaui de "contradiscurso" $(2003,81 s)$.

20 Sobre a adulação e a perfídia, ver Ética, IV, Ap., Cap. 21.

${ }^{21}$ Vale advertir que "a maior parte" dos homens não é equivalente à plebe, mas perpassa a sociedade como um todo. Sobre os costumes, ver Ética II, Def. dos Afetos 27, Exp., p. 353; TP, I, 7; 2003, TTP, XVII.

22 Estes são aptos a suportar e padecer, ao contrário dos primeiros (Ética, P 13, Lema 1, Dem, p. 151; IV, Ap., Cap. 13). Sobre a honestidade, ver Ética, IV, P. 37, Esc. 1. Na abertura do Tratado político, Espinosa anuncia que procurará "não detestar as ações humanas, mas entendê-las" (TP, I, 4).

${ }^{23}$ Ver Ética, III, P. 55, Esc., p. 325; III, Def. Afetos 37; e como contraexemplo, IV, Ap., Cap. 9/

${ }^{24}$ Em Espinosa, o hábito não é uma segunda natureza, como em Suárez.

${ }^{25} \mathrm{Em}$ sua forma intransitiva, o verbo respicio designa o ato de olhar para trás. Embora aqui o verbo seja transitivo, nele se preserva a noção de que o que se leva em consideração é algo já dado.

${ }^{26}$ Sobre a admiração, ver Ética, III, Def. Afetos 4, p. 341. Por se tratar a admiração de uma "imaginação singular" que "não tem nenhuma conexão com outras", a admiração opera na memória coletiva com a instituição de casos lembrados como tais, em sua singularidade.

27 "Dir-se-á talvez que foi por causa da insubmissão dessa gente [ex gentis contumacia]. Mas isto é infantil! Por que esta nação [natio] foi mais insubmissa [contumacior] do que as outras? Seria pela sua natureza? Mas a natureza não cria nações, cria indivíduos, e estes são de nacionalidades distintas em virtude apenas da diversidade da língua, das leis e dos costumes herdados. Só estes dois últimos aspectos, as leis e os costumes, podem fazer com que cada nação [natio] tenha uma índole [ingenium] singular, condições específicas e, enfim, preconceitos próprios. Se, por conseguinte, fosse de admitir que os hebreus foram mais insubmissos [contumaces] do que o resto dos mortais, haveria que o imputar a qualquer deficiência das leis ou dos costumes herdados" (TTP, XVII, G. 217).

28 Se observarmos o deslocamento conceitual realizado no parágrafo VII, 27 do Tratado político e examinado por Chaui (2003), veremos que ali o movimento interno ao texto é em tudo análogo ao movimento que agora flagramos no capítulo XX do Tratado teológico-político: cada qual é composto de dois deslocamentos e o 
que é deslocado são papéis sociais em relação ao vulgo; mas enquanto lá a questão gira em torno de saber quem é o vulgo (o deslocamento é da plebe à nobreza), aqui a questão é saber quem instiga o vulgo (e o deslocamento é dos governados àqueles que aspiram ao poder ou que já o detêm). O que garante a analogia é o fato de ambos os movimentos tratarem de uma mesma relação de poder, em cada um encarada sob um aspecto diferente: enquanto no Tratado teológico-político a ênfase recaiu sobre o aspecto político dessa relação, já no Tratado político, escrito posteriormente, é seu aspecto social que terá realce.

29 Mas também do conformismo e da servidão, como se observa na passagem, anteriormente citada, sobre os súditos suportarem mais facilmente o governo (TTP, XVII, G. 204).

30 Nesse sentido, acentua-se a diferença entre Espinosa e Hobbes, muito próximos tanto pelo diagnóstico da situação - a insegurança que nasce da atuação das seitas religiosas no imperium - como pelo propósito - conter as facções religiosas para garantir a paz, a segurança e a liberdade comuns, e viabilizar a máxima igualdade entre os cidadãos. Mas enquanto Hobbes busca a igualdade pela igual submissão de todos a um poder transcendente (e vê na democracia a licença), para Espinosa é na democracia que há a maior igualdade entre os cidadãos (e a licença tende a ser maior quanto mais o imperium se afasta da democracia). Na base dessa divergência, há duas visões sobre o direito natural. Em missiva a Jelles, datada de 2 de junho de 1674, Espinosa escreve: "a discordância entre Hobbes e eu, sobre a qual me interroga, consiste nisto: que eu conservo o direito natural em bom estado [sartum tectum conservo] [...]" (Ep. 50). A expressão sartum tectum ("em bom estado") talvez esteja aí porque também Hobbes preserva o direito natural, mas não totalmente; ele fala da inviolabilidade de "alguns" dos direitos naturais, mas os limita àqueles direitos que são "necessários para a vida" (De Cive, I, III, 14). Se Hobbes considera que só um poder absoluto pode garantir a supressão de parte substantiva do direito natural e, com isso, viabilizar a paz, a segurança e a liberdade comuns, Espinosa, ao contrário, considera não só que um poder que se pretenda absoluto (no sentido hobbesiano) sofrerá, com maior força, a reação dos indivíduos, numa cadeia de violência, mas que é justamente do esforço de concentrar todo o poder nas mãos de um só ou de poucos que nasce a licença. Embora as supremas potestades tenham direito sobre todas as coisas, o usufruto desse direito, diz Espinosa, não é vantajoso [utile] (TTP, G. 226, p. 301). 


\section{Referências bibliográficas}

ANDRADE, Fernando Dias. Um crisol contra o estado servil. Sobre Espinosa, tratado político, III, 1-9. Ipseitas (São Carlos), vol. 1, n. 2, jul.-dez. 2015, p. 17-35.

AURÉLIO, Diogo Pires. Imaginação e poder. Estudo sobre a filosofia política de Espinosa. Lisboa: Colibri, 2000.

BALIBAR, Étienne. Jus, Pactum, Lex: sur la constitution du sujet dans le Traité Théologico-Politique. Studia spinozana: an international and interdisciplinary series, n. 1, 1985, p. 105-142.

CALVINO, João. A instituição da religião cristã. Tomo 2. Tradução: Carlos Eduardo de Oliveira. São Paulo: Editora UNESP, 2008.

CHAUI, Marilena. Manifestações ideológicas do autoritarismo brasileiro. Belo Horizonte: Autêntica Editora; São Paulo: Editora Fundação Perseu Abramo, 2013. Escritos de Marilena Chaui, v. 2 (Organizador André Rocha).

CHAUI, Marilena. Política em Espinosa. São Paulo: Companhia das Letras, 2003.

DAVID, Antônio. A prática e a teoria. Espinosa contra os filósofos. Síntese (Belo Horizonte), vol. 48, n. 151, maio-ago. 2021, p. 415-451.

DAVID, Antônio. Ad usum vitae. Causalidade e história em Espinosa. doispontos, vol. 16, n. 3, nov. 2019a, p. 1-23.

DAVID, Antônio. Espinosa e a gênese do direito comum. Cadernos Espinosanos, n. 41, jul-dez 2019b, p. 173-215.

DUNKELGRÜN, Theodor. 'Neerlands Israel': Political Theology, Christian Hebraism, Biblical Antiquarianism, and Historical Myth. In: CRUZ, Laura; FRIJHOFF, Willem (ed.). Myth in history, history in myth: proceedings of the third international conference of the society for netherlandic history (New York: June 5-6, 2006). Brill, 2009, p. 201-236.

ESPINOSA, Baruch. Carta 44. Tradução: Antônio David. Cadernos de Ética e Filosofia Política, n. 20, p. 178-81.

ESPINOSA, Baruch. Epistola L. Tradução: Diego Lanciote. Modernos \& Contemporâneos (Campinas), v. 2, n. 4., jul.-dez. 2018, 267-71. 
ESPINOSA, Baruch. Ética. Tradução: Grupo de Estudos Espinosanos. São Paulo: Editora da Universidade de São Paulo, 2015.

ESPINOSA, Baruch. Spinoza Opera. Im Auftrag der Heidelberger Akademie der Wissenschaften hrs. von Carl Gebhardt. Heidelberg, C. Winter, 1972.

ESPINOSA, Baruch. Traité théologico-politique; Traduction: Jacqueline Lagrée et Pierre-François Moreau. Paris: Presses Universitaires de France, 2012.

ESPINOSA, Baruch. Tratado Político. Tradução: Diogo Pires Aurélio. São Paulo: Martins Fontes, 2009.

ESPINOSA, Baruch. Tratado Teológico-político. Tradução: Diogo Pires Aurélio. São Paulo: Martins Fontes, 2003.

FRIJHOFF, Willem. Prophétie et société dans les Provinces-Unis aux XVII e et XVIII e siècles, In: DUPONT-COUCHAT, Marie-Sylvie; FRIJHOFF, Willem; MUCHEMBLED, Robert. Prophètes et Sorciers dans les Pays-Bas XVI ${ }^{e}$ et XVIII siècles. Hachette, 1978, p. 263-362.

HOBBES, Thomas. Do cidadão. Tradução: Janine Ribeiro. São Paulo: Martins Fontes, 2002.

JAMES, Susan. Spinoza on philosophy, religion, and politics. The theologicopolitical treatise. Oxford University Press: 2012.

LAZZERI, Christian. Droit, pouvoir et liberté. Spinoza critique de Hobbes. Paris: Presses Universitaires de France, 1998.

LAZZERI, Christian. Les lois de l'obéissance: sur la théorie spinoziste des transferts de droit. Les Études philosophiques, n. 4, oct-déc. 1987, p. 409438.

MOREAU, Pierre-François. Le Traité théologique-politique. Kriterion, n. 106, dez. 2002, p. 77-88

NADLER, Steven. A book forged in hell: Spinoza's scandalous treatise and the birth of the secular age. Princeton University Press: 2011.

ROWEN, Herbert H. Johan de Witt. Statesman of the "true freedom". Cambridge University Press, 1986. 
SCATTOLA, Merio. Teologia política. Tradução: José Jacinto Correia Serra. Lisboa: Edições 70, 2007.

STEENBAKKERS, Piet. The text of Spinoza's Tractatus Theologico-Politicus. In: MELAMED, Yitzhak Y.; ROSENTHAL, Mochael, A. (ed.) Spinoza's 'theological-political treatise': a critical guide. Cambridge University Press: 2010, p. 29-40.

STERN, Jill. The Orangist Myth, 1650-1672. In: CRUZ, Laura; FRIJHOFF, Willem (ed.). Myth in history, history in myth: proceedings of the Third International Conference of the Society for Netherlandic History (New York: June 5-6, 2006). Brill, 2009, p. 33-52.

STRAUSS, Leo. Spinoza's critique of religion. Translation: E.M. Sinclair. The University of Chicago Press, 1965.

TOMÁS DE AQUINO. Escritos Políticos. Tradução: Francisco Benjamin de Souza Neto. Petrópolis: Vozes, 1995.

TROOST, Wout. William III, the Stadholder-king a political biography. Translated by J.C. Grayson. Routledge, 2016. 